\title{
Development Effects of Humanitarian Crisis and Rural Banditry: A Focus on Southern Kaduna
}

\author{
Humphrey Nchom \\ Institute of International Trade and Development, University of Port Harcourt, Rivers State, Nigeria
}

\begin{abstract}
The complexity of sectarian conflicts in the North West geopolitical zone of Nigeria has sparked renewed interest on its economic, social and political implications. In view of the unending controversies surrounding the complex history of violent conflicts, this paper examines the development effects of humanitarian uprising and rural banditry in Southern Kaduna. The paper adopted a survey research design and utilized a well-structured questionnaire to elicit data from 125 respondents in five local government areas in Southern Kaduna. Combinations of descriptive and inferential statistics in addition to logit regression estimation formed basis for the data analysis. The findings reveal that that high incidence of cattle rustling and village raids increase the odd of poverty in Southern Kaduna. Similarly, it was observed that with high incidence of kidnapping in the study area, the likelihood of poverty increases. Additionally, the findings reveal that high incidence of cattle rustling increases the likelihood of unemployment. The result further reveals that high incidence of village raids increases the odd of unemployment in the study area. The implication of these findings is that the incidence and escalation of cattle rustling and village raids increase socio-economic deprivation with rising levels of poverty and unemployment. It is therefore, reasonable to conclude that the myriad of sectarian conflicts poses a threat to the development of Southern Kaduna and government has failed to adopt appropriate and workable civilian protection strategy in addressing the increasing wave of humanitarian uprising and rural banditry in the affected areas. Owing to the findings, it is recommended amongst others that relevant stakeholders such as government, religious leaders, traditional rulers, community leaders and development partners should build and sustain inter-religious engagement and dialogue as a pathway to sustainable peaceful co-existence and economic prosperity in Southern Kaduna.
\end{abstract}

Keywords: Sectarian conflicts, humanitarian crisis, rural banditry, cattle rustling, village raids, poverty and unemployment

DOI: $10.7176 / \mathrm{JESD} / 11-20-06$

Publication date:October $31^{\text {st }} 2020$

\section{INTRODUCTION}

In recent time, the North West geopolitical zone in Nigeria has remained the epicenter of sectarian conflicts. The region has witnessed a continuing expansion of village raids, ethno-religious violence, kidnapping and highway robbery. Aside being subject of national security and public concern, the continuing expansion of rural banditry and humanitarian crisis in the North West has threatened the means of livelihood of the people and the economy of the region. The multifaceted layers of criminality involved and recurrent nature of the armed banditry have continued to threaten the peaceful co-existence of the people in the affected states. According to West African Network for Peace Building (WANEP, 2020), the multi-dimensional structure of armed banditry requires workable mechanisms to address the threat it poses to peace and security in the affected states. This is because the incidence and pervasiveness of armed banditry has resulted to numerous causalities. Available statistics from the WANEP National Early Warning System (NEWS) reveal that armed banditry resulted to the death of over 1058 people in Zamfara, Kaduna, Katsina, Sokoto and Niger States between January and December, 2019.

The seemingly intractable violent conflicts in the North West have continued to position the region on the spotlight of national dailies and electronic media. The approach followed by past and current governments in understanding the varied forms, causes, patterns and dimensions of the conflict seem to have worsened it rather than providing the required solution. It has further eroded the powers of the traditional rulers and judicial system in finding intended and desired solutions to the lingering conflicts. Notably, the contemporary narrative on rural banditry in the North West reveals a pathetic humanitarian uprising and there is a clarion call for collaboration amongst the relevant stakeholders to address the crisis. Despite the growing presence of security forces in the region, the situation continues to worsen on daily basis with untold hardship on the residents of the affected communities. The affected communities continue to suffer from the spate of insecurity that has engulfed the region (Bagu \& Smith, 2017). The wave of conflicts and reprisal attacks has equally jeopardized the expected progress on the Sustainable Development Goals (SDGs) and worsened the level of underdevelopment in the region.

Like other states in the North West region, Kaduna State has continued to witness an unending civil unrest in the forms of rural banditry, humanitarian crisis and other forms of ethno-religious conflicts. Adamu, Ben \& Gloria (2017) observe that Kaduna State has been experiencing various forms of conflicts since the early 1970s. Notably, WANEP (2018) report identifies Southern Kaduna as a major flashpoint to various dimensions of 
conflicts that have led to huge humanitarian crisis, weakened social capital and breakdown of democratic norms and values. The conflicts have further impacted the economy of the State negatively with increasing incidences of poverty and unemployment. For instance, the Labour Force Statistics of the National Bureau of Statistics (NBS) reveal that Kaduna State has the highest unemployment rate in the North West region with 39.8 percent in the second quarter of 2020 compared to the 31.0 percent recorded in the third quarter of 2018 . This shows an upward trend in the rate of unemployment in the State for the past 20 months.

Furthermore, the Nigerian Living Standard Survey (NLSS) released by NBS covering the period of September, 2018 to October, 2019, revealed that 43.5 percent of people in the State are classified as poor. This is above the national average of 40.1 percent recorded during the same period. Again, the NBS report in 2020 shows that between September, 2018 and October, 2019, Kaduna State recorded high Gini index with 35.2 percent and it is second to Plateau which recorded the highest Gini index with 40.2 percent. This is indicative that Kaduna State has high incidence of income inequality. With over two and half decades of conflicts in Southern Kaduna, there has been growing concern on the development implications of the conflicts. On the basis of the foregoing, this paper examines the development effects of rural banditry and humanitarian crisis in Southern Kaduna.

\section{REVIEW OF RELATED LITARATURE}

\subsection{Theoretical Framework}

\subsubsection{Social Identity Theory}

Tajfel (1978) proposed the social identity theory which assumes that group membership provides people with a sense of their distinct place in the social world in relations to others. It therefore, acts as a practical guide to action by imparting the norms concerning the perceived desirable forms of behaviour associated with a particular group membership. The theory focuses on addressing the ways through which social identities affect people's attitudes and behaviors regarding their in-group and the out-group. It has received widespread recognition considering the glamour for in-group favoritism and out-group discrimination. Sindic \& Condor (2014) are of the view that the underlying assumption of social identity theory is that groups rather than individuals are the main cause of both social conflict and social change.

As a theory of intergroup conflict, social identity theory has been applied to the analysis of a range of issues and problems in group dynamics and intergroup relations. According to Scheepers \& Ellemers (2019), people derive their social identity from the groups to which they belong and this form basis for their actions. Given that ethnic affinities as opposed to other identities, such as social class form basis form people to define themselves in Kaduna state, the social identity theory is considered useful for this study. Additionally, religious and ethnic identities are considered more important than class identity. Therefore, emphasis on such religious and ethnic identity differences tends to trigger ethno-religious crisis among different groups.

\subsubsection{Routine Activity Theory (RAT)}

This theory is credited to Cohen \& Felson (1979). It was developed from the criminological application of rational choice, and focuses on the characteristics of crime rather than the characteristics of the offender. According to Bottoms \& Wiles (1997), the routine activity theory revolves around three things comprising a potential offender, a suitable target, and the absence of a capable guardian. The theory provides insights into the patterns and upward trends of predatory criminal events in the historical context of an evolving society (Hsieh \& Wang, 2018). In accordance with the core elements of this theory, the motivated offenders are individuals who are capable and willing to commit a crime while suitable targets can be persons or objects that are considered by offenders as vulnerable or attractive. On the other hand, guardianship can be a person or an object that is effective in deterring offense to occur. It is assumed that crime is likely to occur when there is a spatial-temporal convergence of three essential elements of crime, namely a motivated offender, an attractive target, and the absence of capable guardianship.

The routine activity theory looks at crime from an offender's point of view. A crime will only be committed if a likely offender thinks that a target is suitable and a capable guardian is absent. It is the offender's assessment of a situation that determines whether a crime will take place or not. It has been argued that the increasing presence and prevalence of under-guarded hinterlands, forestlands and borderlands have provided an enormous opportunity for the pervasiveness of rural banditry. More so, the vulnerability of the rural economy based largely on animal husbandry and crop production and informal activities has been identified as a notable target for crime in the target areas. In addition to the vulnerability of the rural economy to incidences of conflicts, inadequacy and ineffectiveness of government security apparatus in most rural communities in Southern Kaduna and other parts of North West zone define the absence of a capable guardian which increases the escalation of crime in the region. Therefore, conflicts have remained a routine activity in Southern Kaduna following the growing motivation to commit, the increasing availability of target objects and poor guardianship on the parts of government and security agencies. 


\subsection{Empirical Literature}

Salihu (2019) explores the ethnic conflict in Kaduna State to provide some insights into the causes and associated implications. The study revealed that ethnic conflict in Kaduna State is associated with myriad of factors, including fight for supremacy over land, hate speeches, growing economic, social and political inequalities between ethnic groups amongst others. It was further observed that the consequences of conflicts include stress and anxiety on the individuals; breakdown in communities; additional demands on government services and degradation of the local environment. The study acknowledged that the federal and state governments, civil society, religious groups, and communities have responded to the different manifestations of the conflict in a variety of ways, but solutions to ethnic conflict can be achieved through a variety of efforts. Thus, the study recommended that government should check proliferation of fire arms in the hands of unauthorized persons while focusing attention on the prevention of crime.

Ewetan \& Urhie (2014) examine the growing level of insecurity in Nigeria and its implication for socioeconomic development. The study reviewed existing data and found that the level and dimensions of insecurity in Nigeria has increased over time. It is considered as a threat to lives and properties, hindrance to business activities and discourages local and foreign investors. The study further indicates that the wave of insecurity has assumed a dangerous dimension which is threatening socio-economic development and the corporate existence of the country as one geographical entity. Owing to the findings, the study recommends that government must adopt proactive measures in dealing with security issues and threats, through modern methods of intelligence gathering, and sharing among security personnel, training, logistics, motivation, and deploying advanced technology in managing security challenges.

Epron (2019) analyzed the causes and socioeconomic implications of emerging security challenges in Nigeria. The historical method of research and analysis was employed in the study. It was observed from the findings that Nigeria's socio-economic development have been negatively affected by the emergence of security challenges, especially kidnapping, banditry, and cybercrime. The study further revealed that unemployment is one of the leading factors of emerging security challenges in Nigeria. The study however, recommends among others, the need for government to create more job opportunity, provide more social programs, and to re-enforce its security agencies to adequately tackle the security challenges ravaging the country.

\section{RESEARCH METHODOLOGY}

\subsection{Research Design}

Considering the nature of this paper, a survey research design is adopted. The rationale for the adoption of this approach is due to the large population of study and the qualitative nature of this paper. Notably, a survey research design provides the baseline for selecting a sample of respondents from the population of study and administering a well-structured questionnaire to them in order to elicit the required information.

\subsection{Population of the Study}

The target population for this study constitutes all the residents of Southern Kaduna. More importantly, the five local government areas in Southern Kaduna were covered as parts of the target population.

\subsection{Sampling Technique and Sample Size}

This study adopted a combination of purposive and convenience sampling methods. Purposively, the study sample comprises the five local government areas in Southern Kaduna with high incidence of violent conflicts. Convenience sampling is very suitable for survey study with very large or unknown population as it allows for the selection of more readily available or most convenient respondents for the study sample (Cohen, Manion \& Morrison, 2013). The rationale for the adoption of convenience sampling for this study is its efficiency and cost effectiveness in granting the researcher access to readily available respondents who qualify as part of the study sample from whom the required information were sourced. A sample of 25 respondents was randomly selected from each of the five local government areas. Therefore, the sample size for this study is 125 respondents.

\subsection{Model Specification}

This paper adopts logit regression model in estimating the conflict-development nexus in Southern Kaduna. The logit regression allows for estimating the coefficient of a predictor which measures its independent contribution to variation in the dependent variable. Conventionally, the dependent variable takes value between zero and unity. The model set up is provided as follows:

$\mathrm{Y}=\mathrm{B}_{0}+\mathrm{B}_{1} \mathrm{CTR}+\mathrm{B}_{2} \mathrm{VRD}+\mathrm{B}_{3} \mathrm{HWR}+\mathrm{B}_{4} \mathrm{KDP}+\mathrm{Ut}$

Where: $\mathrm{Y}$ defines the development indicators (poverty and unemployment), $\mathrm{CTR}=$ cattle rustling, $\mathrm{VRD}=$ village raids, $\mathrm{HWR}=$ highway robbery, $\mathrm{KDP}=$ kidnapping, $\mathrm{B}_{1}-\mathrm{B}_{4}=$ regression estimates and $\mathrm{Ut}=$ conventional error term. Basically, the logit model involves odd prediction. The formal statement of the linear form of odd prediction model is of the form: 


$$
\frac{p}{1-p}=\mathrm{B}_{0}+\mathrm{B}_{1} \mathrm{CTR}+\mathrm{B}_{2} \mathrm{VRD}+\mathrm{B}_{3} \mathrm{HWR}+\mathrm{B}_{4} \mathrm{KDP}+\mathrm{Ut}
$$

Where: $\frac{p}{1-p}$ defines the odd, $\mathrm{p}$ represents the probability of the event occurring and 1-p denotes the probability of the event not occurring.

The log-linear for the odd prediction model is provided below:

$$
\operatorname{In}\left(\frac{p}{1-p}\right)=\mathrm{B}_{0}+\mathrm{B}_{1} \mathrm{CTR}+\mathrm{B}_{2} \mathrm{VRD}+\mathrm{B}_{3} \mathrm{HWR}+\mathrm{B}_{4} \mathrm{KDP}+\mathrm{Ut}
$$

Where: In $=$ Natural log notation

\subsection{Method of Data Analysis}

This paper adopts both descriptive and inferential statistics in analyzing the primary data sourced from the respondents. Specifically, combinations of mean ratings, frequency distribution and simple percentage in addition to logit regression analysis were applied. The application of the logit regression is necessitated in this paper in order to allow for correct prediction of the expected outcome. The logit regression can also be interpreted from the point of view of the odds of occurrence of the event studied (Borucka, 2020). The odds mainly the probability of an event occurring. In addition the primary data, content analysis was applied on the secondary data sourced from documentary sources.

\section{RESULTS AND DISCUSSION}

\subsection{Demographic Information of the Respondents}

The demographic information of the information of the respondents is summarized in table 1.

\begin{tabular}{|c|c|c|c|}
\hline \multicolumn{2}{|l|}{ Variable } & Frequency & Percentage $(\%)$ \\
\hline \multirow[t]{2}{*}{ Sex } & $\begin{array}{l}\text { Male } \\
\text { Female }\end{array}$ & $\begin{array}{l}74 \\
51\end{array}$ & $\begin{array}{l}59 \\
41\end{array}$ \\
\hline & Total & 125 & 100 \\
\hline \multirow[t]{2}{*}{ Age } & $\begin{array}{l}20-39 \text { years } \\
40-59 \text { years } \\
60 \text { years and above }\end{array}$ & $\begin{array}{l}39 \\
61 \\
25\end{array}$ & $\begin{array}{l}31 \\
49 \\
20\end{array}$ \\
\hline & Total & 125 & 100 \\
\hline \multirow[t]{2}{*}{ Marital status } & $\begin{array}{l}\text { Single (never married) } \\
\text { Married } \\
\text { Divorced } \\
\text { Living together } \\
\text { Separated }\end{array}$ & $\begin{array}{l}19 \\
87 \\
11 \\
5 \\
3 \\
\end{array}$ & $\begin{array}{l}15 \\
70 \\
9 \\
4 \\
2 \\
\end{array}$ \\
\hline & Total & 125 & 100 \\
\hline \multirow[t]{2}{*}{ Educational attainment } & $\begin{array}{l}\text { Primary education } \\
\text { Secondary education } \\
\text { Tertiary education } \\
\text { Vocational education } \\
\text { No formal education }\end{array}$ & $\begin{array}{l}5 \\
25 \\
70 \\
25 \\
0\end{array}$ & $\begin{array}{l}4 \\
20 \\
56 \\
20 \\
0 \\
\end{array}$ \\
\hline & Total & 125 & 100 \\
\hline \multirow[t]{2}{*}{ Local government area of residence } & $\begin{array}{l}\text { Sanga } \\
\text { Kachia } \\
\text { Kaura } \\
\text { Jema'a } \\
\text { Zango Kataf }\end{array}$ & $\begin{array}{l}25 \\
25 \\
25 \\
25 \\
25\end{array}$ & $\begin{array}{l}20 \\
20 \\
20 \\
20 \\
20\end{array}$ \\
\hline & Total & 125 & 100 \\
\hline
\end{tabular}

Table 1: Summary of demographic information of the respondents

\section{Source: Author's computation based on data elicited from the respondents}

As observed in table 1, the sex distribution of the respondents reveals that $74(59 \%)$ of them are male while the remaining $51(41 \%)$ are female. This is indicative that majority of the sampled respondents are male. It was equally observed from the age distribution that $39(31 \%)$ of the respondents are between 20 and 39 years, $60(49 \%)$ of them are between 40 and 59 years while $25(20 \%)$ of them are 60 years and above. The marital status of the respondents reveals that $19(15 \%)$ respondents are single, $87(70 \%)$ are married, $11(9 \%)$ are divorced, $5(4 \%)$ are living together and $3(\%)$ are separated. Again, the distribution of the respondents based on educational attainment 
indicates that $5(4 \%)$ of them acquired primary education, $25(20 \%)$ of them had secondary education, $70(56 \%)$ of them had tertiary education while $25(20 \%)$ of them had vocational education. This is an indication that majority of the sampled respondents had higher education. The distribution of the respondents across the five local government areas shows a 20 percent population in each of the area. This is indicative that the respondents are evenly spread in the study area.

\subsection{Nature and Causes of Humanitarian Crisis and Rural Banditry}

The dimensions and causes of humanitarian crisis and rural banditry in Southern Kaduna based on the information elicited from the target respondents are summarized in table 2 and 3.

Table 2: Nature of humanitarian crisis and rural banditry

\begin{tabular}{|l|l|l|l|l|l|l|}
\hline Item & $\begin{array}{l}\text { Very serious } \\
\text { problem }\end{array}$ & $\begin{array}{l}\text { Serious } \\
\text { problem }\end{array}$ & $\begin{array}{l}\text { Minor } \\
\text { problem }\end{array}$ & $\begin{array}{l}\text { Not a problem } \\
\text { at all }\end{array}$ & Total & $\begin{array}{l}\text { Mean } \\
\text { Score }\end{array}$ \\
\hline Cattle rustling & 76 & 38 & 11 & 0 & 125 & 3.52 \\
\hline Village raids & 84 & 33 & 8 & 0 & 125 & 3.61 \\
\hline Highway robbery & 66 & 29 & 18 & 12 & 125 & 3.19 \\
\hline kidnapping & 69 & 31 & 22 & 3 & 125 & 3.33 \\
\hline
\end{tabular}

Source: Author's computation based on data elicited from the respondents

As observed from table 2, cattle rustling, village raids, highway robbery and kidnapping are associated with high mean scores which are greater than the critical mean rating of 2.5. This is indicating that the incidence and pervasiveness of humanitarian crisis and rural banditry are in the forms of cattle rustling, village raids, highway robbery and kidnapping. Following their respective mean ratings, village raid is identified as the predominant form of violent crisis in the study area given that it is associated with the highest mean rating. It therefore, follows from the foregoing that Southern Kaduna has been ravaged by increasing incidence of humanitarian crisis and rural banditry.

Table 3: Causes of humanitarian crisis and rural banditry

\begin{tabular}{|l|l|l|l|l|l|l|}
\hline Item & Very high & High & Low & Very low & Total & Mean Score \\
\hline Ethno-religious intolerance & 81 & 33 & 9 & 2 & 125 & 3.62 \\
\hline Greed & 22 & 39 & 35 & 29 & 125 & 2.43 \\
\hline Insecurity & 61 & 34 & 22 & 8 & 125 & 3.18 \\
\hline Psychological needs & 57 & 40 & 19 & 9 & 125 & 3.16 \\
\hline Political interest & 78 & 35 & 8 & 4 & 125 & 3.49 \\
\hline
\end{tabular}

Source: Author's computation based on data elicited from the respondents

Table 3 reveals that humanitarian crisis and rural banditry in Southern Kaduna are linked to ethno-religious intolerance, insecurity and psychological needs. It is further revealed that humanitarian crisis and rural banditry are politically motivated. In accordance with the mean ratings, ethno-religious intolerance is observed as the major cause of humanitarian crisis and rural banditry in the study area. In addition to ethno-religious intolerance, the mean ratings reveal that political interest, insecurity and psychological needs are sources of humanitarian crisis and rural banditry. This attests to the complexity of the sources of the growing violent crisis in the study area.

\subsection{Development Implications of Humanitarian Crisis and Rural Banditry}

Poverty and unemployment were utilized in measuring the development implications of the underlying incidence of humanitarian crisis and rural banditry in the study area. The outcomes of the estimated logit regression model are summarized in table 4-5. 
Table 4: Estimated logit regression for model 1

\begin{tabular}{|c|c|c|c|c|}
\hline \multicolumn{5}{|c|}{ Dependent Variable: POV } \\
\hline \multicolumn{5}{|c|}{ Method: ML - Binary Logit (Newton-Raphson / Marquardt steps) } \\
\hline \multicolumn{5}{|c|}{\begin{tabular}{l|l|} 
Sample: 1125 & \\
\end{tabular}} \\
\hline \multicolumn{5}{|c|}{ Included observations: 125} \\
\hline Variable & Coefficient & Std. Error & z-Statistic & Prob. \\
\hline CTR & 0.063661 & 0.021836 & 2.915414 & 0.0043 \\
\hline VRD & 0.330604 & 0.129538 & 2.552177 & 0.0198 \\
\hline HWR & 0.049543 & 0.151720 & 0.326544 & 0.7440 \\
\hline KDP & 0.349064 & 0.166059 & 2.102046 & 0.0355 \\
\hline Mean dependent var & 0.496000 & \multicolumn{2}{|c|}{ S.D. dependent var } & 0.501996 \\
\hline S.E. of regression & 0.498159 & \multicolumn{2}{|c|}{ Akaike info criterion } & 1.410330 \\
\hline Sum squared resid & 30.02768 & \multicolumn{2}{|c|}{ Schwarz criterion } & 1.500836 \\
\hline Log likelihood & -84.14563 & \multicolumn{2}{|c|}{ Hannan-Quinn criter. } & 1.447098 \\
\hline Deviance & 168.2913 & \multicolumn{2}{|c|}{ Restr. deviance } & 173.2788 \\
\hline Avg. log likelihood & -0.673165 & & & \\
\hline
\end{tabular}

Source: Author's computation based on data elicited from the respondents

As observed from table 4, cattle rustling, village raids and kidnapping are associated with significant positive coefficients. This indicates that high incidence of cattle rustling and village raids increase the odd of poverty in Southern Kaduna. Similarly, it was observed that with high incidence of kidnapping in the study area, the likelihood of poverty increases. The implication of these findings is that the likelihood that people are poor tends to increase with higher incidence of humanitarian crisis and rural banditry. This could be linked to the negative effects of cattle rustling, village raids and kidnapping on the livelihood of the people and socio-economic infrastructure. Thus, poverty has remained a major development issue in Southern Kaduna following the increasing incidence humanitarian crisis and rural banditry.

Table 5: Estimated logit regression for model 2

\begin{tabular}{|c|c|c|c|c|}
\hline \multicolumn{5}{|c|}{ Dependent Variable: UNEMP } \\
\hline \multicolumn{5}{|c|}{ Method: ML - Binary Logit (Newton-Raphson / Marquardt steps) } \\
\hline \multicolumn{5}{|c|}{ Included observations: 125} \\
\hline Variable & Coefficient & Std. Error & z-Statistic & Prob. \\
\hline CTR & 0.041941 & 0.010895 & 3.849564 & 0.0000 \\
\hline VRD & 0.073610 & 0.202608 & 0.026918 & 0.0058 \\
\hline HWR & -0.001314 & 0.152579 & -0.008614 & 0.9931 \\
\hline KDP & -0.010543 & 0.150819 & -0.069904 & 0.9443 \\
\hline Mean dependent var & 0.456000 & \multicolumn{2}{|l|}{ S.D. dependent var } & 0.500065 \\
\hline S.E. of regression & 0.506276 & \multicolumn{2}{|l|}{ Akaike info criterion } & 1.442739 \\
\hline Sum squared resid & 31.01415 & \multicolumn{2}{|l|}{ Schwarz criterion } & 1.533245 \\
\hline Log likelihood & -86.17120 & \multicolumn{2}{|l|}{ Hannan-Quinn criter. } & 1.479507 \\
\hline Deviance & 172.3424 & \multicolumn{2}{|l|}{ Restr. Deviance } & 172.3175 \\
\hline Avg. log likelihood & -0.689370 & & & \\
\hline
\end{tabular}

\section{Source: Author's computation based on data elicited from the respondents}

The estimated logit regression model in table 5 shows the link between unemployment and underlying measures of humanitarian crisis and rural banditry in Southern Kaduna. As observed from the regression estimates, high incidence of cattle rustling increases the likelihood of unemployment in Southern Kaduna. Again, the result further reveals that high incidence of village raids increases the odd of unemployment in the study area. The implication of these findings is that the prevalence of cattle rustling and village raids increases the incidence of socio-economic deprivation with rising level of unemployment. It therefore, follows from the findings that the probability joblessness amongst the residents of Southern Kaduna tends to increase with the increasing incidences of humanitarian crisis and rural banditry.

\subsection{Effectiveness of Government/Security Agencies' Efforts at Addressing Humanitarian Crisis and Rural Banditry}

The efforts of the relevant stakeholders, government and security agencies in tackling the rising levels of humanitarian crisis and rural banditry in Southern Kaduna were assessed in order to gain insights into their effectiveness. The statistical summary of the survey is presented in table 6-7. 
Table 6: Summary of the effectiveness of government efforts in tackling the rising levels of humanitarian crisis and rural banditry

\begin{tabular}{|c|c|c|}
\hline Item & Frequency & Percentage (\%) \\
\hline Very satisfied & 0 & 0 \\
\hline Fairly satisfied & 2 & 1.6 \\
\hline Slightly dissatisfied & 17 & 13.6 \\
\hline Very dissatisfied & 106 & 84.8 \\
\hline
\end{tabular}

Source: Author's computation based on data elicited from the respondents

Table 7: Summary of the level of the respondents' satisfaction regarding the efforts of security agencies in tackling the rising levels of humanitarian crisis and rural banditry

Table 6 shows the distribution of the respondents regarding their views on the effectiveness of government's efforts in addressing the incidences of humanitarian crisis and rural banditry. It was found from the survey that 94 $(75.2 \%)$ respondents are of the view that government's efforts are very ineffective while $22(17.6 \%)$ respondents consider government's efforts as slightly ineffective. However, only $9(7.2 \%)$ respondents are of the opinion that government's efforts are slightly effective. Following the outcome of the survey, government's efforts can be adjudged as ineffective in addressing the prevalence of humanitarian crisis and rural banditry. In addition to the efforts of government, it was found that, on balance, the respondents are dissatisfied with the efforts of the security agencies. Specifically, the survey reveals that $106(84.8 \%)$ respondents are very dissatisfied with the efforts of the security agencies. It was further observed that $17(13.6 \%)$ respondents are slightly dissatisfied while only $2(1.6 \%)$ respondents are fairly satisfied. The findings suggest that the performances of security agencies in handling the conflicts in Southern Kaduna are below people's expectation.

\section{Conclusion and Recommendations}

The humanitarian crisis and rural banditry have further added to the increased wave of civil unrest in Southern Kaduna. The sectarian conflicts which define humanitarian crisis and rural banditry as identified by this paper are in the forms of cattle rustling, village raids, highway robbery and kidnapping. These conflicts are underlined by multiple factors such as ethno-religious intolerance, political interests, insecurity and psychological needs. It was therefore, observed that ethno-religious intolerance has dominated the underlining factors as the major source of sectarian conflicts in the study area. However, approaches that support expanded operation of security agencies have been introduced by both current and previous governments in the State. This is based on the rationale that security forces could help resolve the crisis associated with the emergence and escalation of humanitarian crisis and rural banditry. Unfortunately, the people are very dissatisfied with the performance of the security agencies and governments' efforts have been adjudged as grossly ineffective. Findings of this paper further indicate that the sectarian conflict in Southern Kaduna is associated with incidences of poverty and unemployment. It is therefore, reasonable to conclude that the myriad of humanitarian crisis and rural banditry poses a great threat to the development of Southern Kaduna. Another important conclusion drawn from this paper is that government has failed to adopt appropriate and workable civilian protection strategy in addressing the increasing wave of humanitarian uprising and rural banditry in Southern Kaduna. Given the findings, the following recommendations are proffered:

1. Relevant stakeholders such as government, religious leaders, traditional rulers, community leaders and development partners should build and sustain inter-religious engagement and dialogue as a pathway to sustainable peaceful co-existence and economic prosperity in Southern Kaduna.

2. Government should adopt appropriate and effective civilian protection strategy in addressing the incidences of humanitarian uprising and rural banditry in order to ensure safety of lives and properties while building on peace for economic growth and development.

3. There should be synergy among security agencies in their operations and an independent judicial commission of inquiry should be established to investigate allegations of collateral damage and other rights violation by security agencies.

4. Government should prioritize infrastructural development and create enabling environment for private sector investments in order to provide gainful employment for the teeming population and reduce the level of poverty.

\section{References}

Adamu, A., Ben, A. \& Gloria, C. (2017). Nigeria: Southern Kaduna and the atrocities of Hausa- Fulani Muslim herdsmen. Working Paper, 6, World Watch Research (WWR), Open Doors International. DOI: 10.13140/RG.2.2.30473.13924

Ayegba, U. S. (2015). Unemployment and poverty as sources and consequence of insecurity in Nigeria: The Boko Haram insurgency revisited. African Journal of Political Science and International Relations, 9(3), 90-99.

Bagu, C. \& Smith, K. (2017). Past is prologue: Criminality and reprisal attacks in Nigeria's Middle Belt, 
Washington, DC: Search for Common Ground.

Borucka, A. (2020). Logistic regression in modeling and assessment of transport services. Open Engineering, 10(1), 26-34.

Cohen, L. E., \& Felson, M. (1979). Social change and crime rate trends: A routine activity approach. American sociological review, 588-608.

Cohen, L., Manion, L., \& Morrison, K. (2013). Research methods in education. routledge.

Epron, S. (2019). Emerging Security Threats: Factors and Implications for Nigeria's Socio-Economic Development 2015-2019. Journal of Economics, 7(2), 141-149.

Ewetan, O. O., \& Urhie, E. (2014). Insecurity and socio-economic development in Nigeria. Journal of Sustainable Development Studies, 5(1).

Salihu, M. (2019). A Review of Ethnic Conflict in Kaduna State, Nigeria. International Journal of Current Innovations in Advanced Research, 2(8), 14-28.

Scheepers, D., \& Ellemers, N. (2019). Social identity theory. In Social Psychology in Action (pp. 129-143). Springer, Cham.

Sindic, D., \& Condor, S. (2014). Social identity theory and self-categorisation theory. In The Palgrave handbook of global political psychology (pp. 39-54). Palgrave Macmillan, London.

Tajfel, H. (1978). Intergroup behavior. Introducing Social Psychology.-NY: Penguin Books, 401-466.

WANEP (2018). Armed bandits, abduct more than 140 People in Birnin-Gwari in Kaduna State, Nigeria." WANEP, News Quick Update. www.wanepnigeria.org

WANEP (2020). Addressing armed banditry in the North-West region of Nigeria: Exploring the potentials of a multi-dimensional conflict management approach. Policy Brief 